\title{
SELECTED AGRICULTURAL PROVERBS AND SINDHI PEASANTS' INDIGENOUS KNOWLEDGE - A SOURCE OF ORAL HISTORY
}

\author{
Zaffar Iqbal Junejo \\ Azharudin Mohamed Dali
}

\begin{abstract}
At present, the research on peasants in Sindh, Pakistan rarely enfolds their folk wisdom, traditions or oral history. The academia has distantly observed and discussed the peasants economic and tenancy rights. Other areas of the peasants' life - which are acknowledged merely as a folklore - have not been given considerate focus, especially their worldview based on indigenous knowledge and oral history. This study examines selected agricultural proverbs, grouped into themes and find out their usage frequency. These proverbs, their preservations, and continuity from one generation to another has become one traditional source for the indigenous wisdom of the agrarian people and the oral history.
\end{abstract}

\section{Introduction}

Sindh a province of Pakistan is the abode of 47.89 .89 million people; its $61 \%$ populations speak Sindhi as their mother tongue which is one of the oldest languages of the Indian subcontinent. Sindhi proverbs are the collective treasure of generations. The origin and definite inception is still a grey area.

Most of the folklorists agree that proverbs are collectively ascribed and have intrinsic value. Sindhi proverbs are always communicated in the third form such as it is said'; the implicit meaning is 'our elders have said'. Sometimes, the question is added before the utterance. It starts; "have you not heard" 2 . An affixed question sets the context for the proverbs. Another form to express the proverbs is a generic statement, and in most of the cases, these statements don't possess the subject and object. However, in either case, the proverbs are strong interpersonal communication tools. ${ }^{3}$ The agriculture proverbs mirror the peasants' image and realize them that they are part of the society. ${ }^{4}$ The usage of proverbs demands the contextual understanding and linguist delicacy for effective communication and pass on to the young generation. The women are the custodian as well as source to pass them from one generation to another generation. ${ }^{5}$ Technically, the proverbs fall into the category of folk media. The other forms of folk media, including proverbs, are puppet shows, old tales, and folk songs. ${ }^{6}$ Sindh's enriched oral culture has enabled peasants to share their experiential learning through proverbs. Some of these proverbs are commonly found across the province.

Otaq is a male sitting place which plays an important role in the social fabric of Sindhi society. At places like Otaqs (a male sitting places), communal wells, the workplaces, or even at homes the proverbs are disseminated and transferred from the older generation to the younger generations. It happens as, in the places, people of different age groups and even people belonging to various social strata gather. The informal usage of the proverbs indirectly trains the younger generation to step in the sphere of maturity. ${ }^{7}$ The peasants' maturity demands hard work in fields, honesty, dedication, self-reliance, and wisdom. Therefore, agriculture proverbs orient the 
peasant to observe, learn and understand the various traditional skills related to the land, its preparation, sowing, harvesting, and its sociology - how possession of grains determine the status of the holder in the society.

Traditionally, these proverbs are used to pass on the indigenous knowledge, enforce the common values and promote the general good. At the one level, these proverbs support the socio-cultural relationship within the community and encourage the societal coherence. But the usage of the proverbs in ordinary conversations and discussions creates imageries for clear understanding. ${ }^{8}$ It also carries the historical learning and upholds the authority of the conversant. In addition to that, the learning context permits the peasant to apply proverbs as a tool to guide, suggest, explain and reinterpret the day to day, societal encounters. Thus, peasants' capacity is enhanced to communicate effectively about the folk wisdom as well as experiential learning about land, landlord and revenue officials. Their utterances create a space for the speakers and listeners to explore the common ground, where dialogue takes place.

Sindhi peasants' micro-sociology induces them to create solidarity; in doing so, the proverbs provide a common ground. In addition to that agricultural proverbs complement in normative, cognitive, dialogical segments of holistic education of the peasantry. The continuous changing environment has raised a question that how long peasants' proverbs will be relevant for society. ${ }^{9}$ Therefore, it is essential that most of them need reinterpretation for continued relevance. Apart from education, the proverbs are used to entertain and pinpoint the historical context of various events and personalities.

\section{Methodology}

A thread based methodology was applied: a) list of selected agriculture proverbs appeared in Sindhi books published from 1889 to 2017 was made, b) these proverbs were categorized into themes, c) topographically diversified villages were selected riverine area (Karo Khaho, District Jamshoro), arid area (Shah AwaisKarni, District Jamshoro) and irrigated area (Boriri, District Dadu), d) Focused Group Discussions (FGDs) were conducted, e) the themes were written on flip charts; f) facilitator read out proverbs and initiated the dialogue, g) the lead question was to identify the proverbs which were used in daily conversation of the peasants to express some idea about agriculture or agriculture-related disciplines, h) each identified proverb was given a score of one per participant, i) allotted numbers were added to calculate the frequency and $\mathrm{j}$ ) the proverbs from each category having the highest cumulative percentage were contextualized and discussed. However, the selection of participants was done based on their residential status (i.e. permanent residents were selected), and family occupation (i.e. farming). The total number of participants at three locationss was 99 - Karo Khaho: 35; Boriri: 40; and Shah AwaisKarni: 24. 
Figure 1: Location map of areas (villages), where Focused Group Discussions were conducted

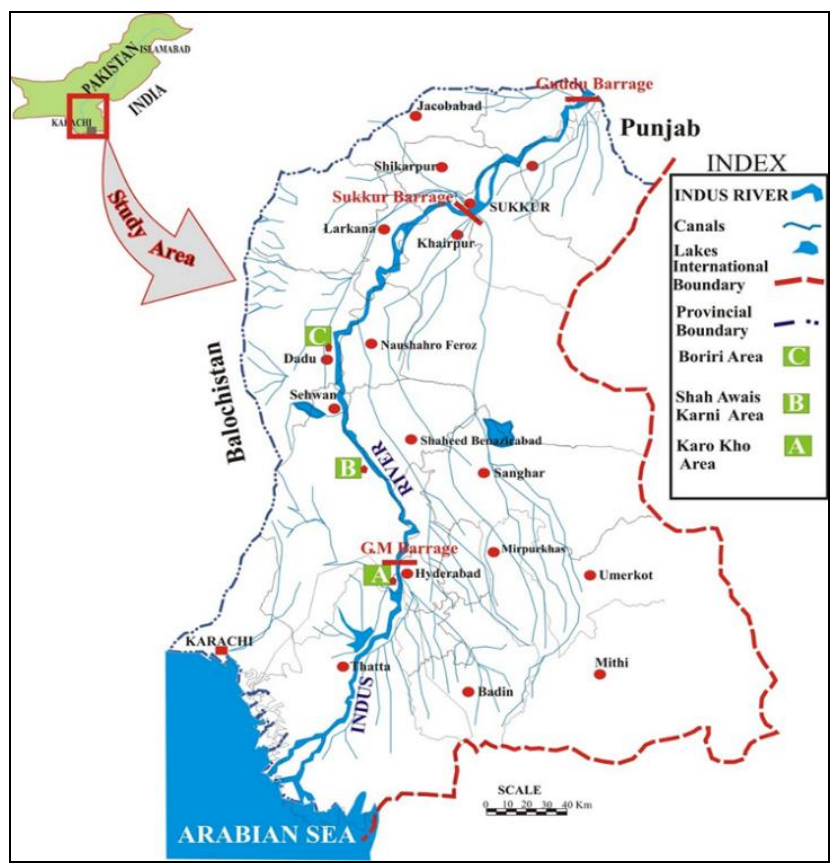

The study's locale is in villages of Dadu and Jamshoro districts of Sindh province, Pakistan. Sindh is the second largest province of Pakistan. It has derived its name from Indus river - commonly called 'Sindhu'. These villages are purposively selected, considering the topographical diversity. The Karo Khaho Area (A) falls into the riverine area, Shah AwaisKarni (B) belongs to the arid zone of Sindh, Boriri Village exists into the irrigated area of Sukkur Barrage Canal System.

The utterance of agricultural proverbs in the peasants' conversation is a natural method to communicate, and thus oral practice transfers indigenous knowledge to the younger generations. Total selected agriculture proverbs were 49, and these were categorized into 4 themes such as Grains and Social Status, Seed and Seedling, Tillage and Home Affairs and Peasants Indigenous Knowledge.

Table 1: Themes, Number of Proverbs and Percentages

\begin{tabular}{|l|r|r|}
\hline \multicolumn{1}{|c|}{ Themes } & \multicolumn{1}{|c|}{$\begin{array}{c}\text { Number of } \\
\text { Proverbs }\end{array}$} & Percentages \\
\hline Grains and Social Status & 15 & 30.6 \\
\hline Seed and Seedling & 5 & 10.2 \\
\hline Tillage and home affairs & 4 & 8.1 \\
\hline Peasants' Indigenous Knowledge & 25 & 51 \\
\hline Total & 49 & 99.1 \\
\hline
\end{tabular}

Table 1 shows that, out of the 49 proverbs, peasant listed the fifteen $(30.6 \%)$ about grain and social status; five $(10.2 \%)$ were related to seed and seedlings; four $(8.1 \%)$ associated with tillage and home affairs, and the remaining $25(51 \%)$ grouped under the peasants' indigenous knowledge.

The relevant proverbs, subject to their content and message were clustered under different themes. The proverb having the highest Cumulative Frequency Usage (CFU) in each theme is placed in ascending order and discussed. 


\section{Table 2: Theme, Proverbs' Frequency Usage and Percentage at Villages and Cumulative Frequency \& Percentage}

\begin{tabular}{|c|c|c|c|c|c|c|c|c|c|}
\hline \multicolumn{10}{|c|}{ Theme: Grains and Social Status } \\
\hline \multirow{2}{*}{$\begin{array}{l}\text { S. } \\
\text { No }\end{array}$} & \multirow{2}{*}{ Proverbs } & \multicolumn{2}{|c|}{$\begin{array}{c}\text { Karo Khahu } \\
\text { (35 Participants) }\end{array}$} & \multicolumn{2}{|c|}{$\begin{array}{c}\text { Boriri } \\
\text { (40 Participants) }\end{array}$} & \multicolumn{2}{|c|}{$\begin{array}{l}\text { Shah AwaisKarni } \\
\text { (24 Participants) }\end{array}$} & \multicolumn{2}{|c|}{$\begin{array}{c}\text { Cumulative } \\
\text { (99 Participants) }\end{array}$} \\
\hline & & Frequency & $\%$ & Frequency & $\%$ & Frequency & $\%$ & Frequency & $\%$ \\
\hline 1 & $\begin{array}{l}\text { UtamKheti, MadeyamWapar, NechNokri, } \\
\text { PenannBekar - Begging is worthless, } \\
\text { employment is lowly, business expands } \\
\text { quickly, but agriculture has the highest } \\
\text { value among all }\end{array}$ & 7 & 20.0 & 8 & 20.0 & 4 & 16.7 & 19 & 19.2 \\
\hline 2 & $\begin{array}{l}\text { Ann Ahe Ta Iman Ahe - Faith depends on } \\
\text { grain (in stomach) }\end{array}$ & 6 & 17.1 & 7 & 17.5 & 4 & 16.7 & 17 & 17.2 \\
\hline 3 & $\begin{array}{l}\text { Ann NaManhango, PerianNakorra- } \\
\text { Neither grain is costly, nor is the beloved's } \\
\text { disliked }\end{array}$ & 3 & 8.6 & 4 & 10.0 & 2 & 8.3 & 9 & 9.1 \\
\hline 4 & $\begin{array}{l}\text { Aghu Allah Jo Watt Wadero Jo - A } \\
\text { common rate exists, but measuring } \\
\text { standard is set by the landlord }\end{array}$ & 3 & 8.6 & 2 & 5.0 & 1 & 4.2 & 6 & 6.1 \\
\hline 5 & $\begin{array}{l}\text { An Pali ZatBhali - Grain store is the sign } \\
\text { of nobility }\end{array}$ & 2 & 5.7 & 2 & 5.0 & 2 & 8.3 & 6 & 6.1 \\
\hline 6 & $\begin{array}{l}\text { Change Je Cheech, Barrage's } \\
\text { PechBorreY'n Tare - A friendship with } \\
\text { the landlord, the outlet from barrage is not } \\
\text { good }\end{array}$ & 2 & 5.7 & 3 & 7.5 & 1 & 4.2 & 6 & 6.1 \\
\hline 7 & $\begin{array}{l}\text { Paet Mein Lul, Goathe Mein Hul-When } \\
\text { there is bread in the stomach, there is life } \\
\text { in the village }\end{array}$ & 2 & 5.7 & 2 & 5.0 & 2 & 8.3 & 6 & 6.1 \\
\hline 8 & $\begin{array}{l}\text { Gana, Abhu'nHaryunKhada, } \\
\text { PucharKhadaJhar, ChhaKhanne } \\
\text { Zamindar, ChhaKhanne Sarkar-The } \\
\text { peasants ate sweet buds and the birds ate } \\
\text { grains, what remains for the landlord and } \\
\text { the revenue officer? }\end{array}$ & 2 & 5.7 & 3 & 7.5 & 1 & 4.2 & 6 & 6.1 \\
\hline 9 & $\begin{array}{l}\text { AjjaBbijKhoteKanhe - Still there is no } \\
\text { shortage of seed }\end{array}$ & 2 & 5.7 & 2 & 5.0 & 1 & 4.2 & 5 & 5.1 \\
\hline 10 & $\begin{array}{l}\text { Ann Je Pali Ghar Mien Bhali, Jal Je } \\
\text { MachiJal Mien Bhali - Grain should be } \\
\text { kept/stored at home, just like fish is well } \\
\text { kept in water }\end{array}$ & 1 & 2.9 & 2 & 5.0 & 1 & 4.2 & 4 & 4.0 \\
\hline 11 & $\begin{array}{l}\text { Ann jo Tan Sa'n, Man Jo Gunn } \\
\text { S'anSubhandAhe - The grain shapes the } \\
\text { body, and a soul sets the good character }\end{array}$ & 1 & 2.9 & 1 & 2.5 & 1 & 4.2 & 3 & 3.0 \\
\hline 12 & Ann, Noor - Grain is the light of life & 1 & 2.9 & 1 & 2.5 & 1 & 4.2 & 3 & 3.0 \\
\hline 13 & $\begin{array}{l}\text { Dali Danna, KuddanKutana - Where the } \\
\text { grain is stored, even there pimps are } \\
\text { joyous }\end{array}$ & 1 & 2.9 & 1 & 2.5 & 1 & 4.2 & 3 & 3.0 \\
\hline 14 & $\begin{array}{l}\text { JadhanKanno Karo Thendo, } \\
\text { TadhanPaetBheDushmanThendo - When } \\
\text { bumper crop happens, enimity occurs even } \\
\text { among the blood relatives }\end{array}$ & 1 & 2.9 & 1 & 2.5 & 1 & 4.2 & 3 & 3.0 \\
\hline 15 & $\begin{array}{l}\text { JahanjiGhar Mein KhaheTanji Chari be } \\
\text { Dhahi - In a home with a place to store } \\
\text { grain, even a foolish lady seems clever }\end{array}$ & 1 & 2.9 & 1 & 2.5 & 1 & 4.2 & 3 & 3.0 \\
\hline
\end{tabular}


1. UtamKheti, WadhandarrWapar, NechNokri, PenannBekar-Cumulative Frequency Usage (CFU): $19.2 \%$

Begging is worthless, employment is a lowly job, business expands quickly, but agriculture has the highest value among all

The proverb has historical roots that how the Sindhi society has evolved. Before Sindh became part of the British Empire, its agriculture was dependent on the monsoon rains and floods in the Indus river. Another ancestors' livelihood trend was to raise livestock. One proverb says, Sindh KannTeYaThannnTe ${ }^{10}$ (Sindh depends on either milk or grain). One of the employment segments was self-employment through opening grocery shops in villages or trading between villages. The first one has a quick chance of expansion due to the high rate of interest, and difficult to decipher the inscribed calculation of Bania, whose pen ${ }^{11}$ was powerful and the conversation was persuasive. Later, the British introduced the canal irrigation system in Sindh and established necessary bureaucracy and government departments. ${ }^{12}$ The then newlycreated service sector consumed a huge number of people. But, the proverb calls the service "Neech" (low) due to its obeying nature.

\section{Ann Ahe Ta Iman Ahe-CFU: $17.2 \%$}

Faith depends on grain (in the stomach)

Culturally, grain is likened to life, and water is considered a living saint in Sindh. ${ }^{13}$ The proverb has a philosophical message for the masses. Sindh faces droughts with a certain frequency which cause crop failure. ${ }^{14}$ The epidemics also add to the peasants' suffering, and its prey became the lower class. ${ }^{15}$ In 1917-18, influenza killed around $40 \%$ population of Sindh's countryside. ${ }^{16}$ Thus, the availability of grains at home gives a person a confidence to interact with society. It is an indication that persons' liberty is associated with the assured availability of the grains at the home.

\section{Ann Na Manhango, Perian Na Korra-CFU: $9 \%$}

Neither grain is costly, nor is the beloved disliked

The occurrence of the disasters and hazards ${ }^{17}$ used to push the hoarders to store the grain and sell it at high prices. But, a proverb says that in all situations, the grain has more weight, because it sustains the life. Thus, it is cheap, whatever its price maybe. The second part of the proverb, states that the beloved is always dear. It emphasizes that in what situations or timings she/he visits the place, neither the occasion is disliked, nor is the visit discouraged. Like the grain, the beloved is always welcomed. 


\section{Table 3: Theme, Proverbs' Frequency, Percentage at Villages and Cumulative} Frequency \& Percentage

\begin{tabular}{|c|c|c|c|c|c|c|c|c|c|}
\hline \multicolumn{10}{|c|}{ Theme: Seed and Seedling } \\
\hline \multirow{2}{*}{ S. No } & \multirow{2}{*}{ Proverbs } & \multicolumn{2}{|c|}{$\begin{array}{c}\text { Karo Khahu } \\
\text { (35 Participants) }\end{array}$} & \multicolumn{2}{|c|}{$\begin{array}{c}\text { Boriri } \\
\text { (40 Participants) }\end{array}$} & \multicolumn{2}{|c|}{$\begin{array}{l}\text { Shah AwaisKarni } \\
\text { (24 Participants) }\end{array}$} & \multicolumn{2}{|c|}{$\begin{array}{c}\text { Cumulative } \\
\text { (99 Participants) }\end{array}$} \\
\hline & & Frequency & $\%$ & Frequency & $\%$ & Frequency & $\%$ & Frequency & $\%$ \\
\hline \multirow[t]{2}{*}{1} & Bbij Ta Nijj-Seed must be pure & 9 & 25.7 & 14 & 35.0 & 8 & 33.3 & 31 & 31.3 \\
\hline & $\begin{array}{l}\text { JahroBijj, TahrroSalo - The seedling } \\
\text { copies the seed }\end{array}$ & 8 & 22.9 & 8 & 20.0 & 4 & 16.7 & 20 & 20.2 \\
\hline 2 & $\begin{array}{l}\text { BijjKhoteKanhe-There is no shortage } \\
\text { of seed if the intention of sowing is } \\
\text { there }\end{array}$ & 5 & 14.3 & 7 & 17.5 & 5 & 20.8 & 17 & 17.2 \\
\hline 3 & $\begin{array}{l}\text { ChhidiPokha, Dumba Sang - Better } \\
\text { harvest is obtained with scattered } \\
\text { seedlings }\end{array}$ & 8 & 22.9 & 5 & 12.5 & 4 & 16.7 & 17 & 17.2 \\
\hline 4 & $\begin{array}{l}\text { JhahriBbaniTahroBbij, } \\
\text { Tahe'nSaliBhar Na Dijj - No worries } \\
\text { about sprouting, if the seed and land } \\
\text { are good }\end{array}$ & 5 & 14.3 & 6 & 15.0 & 3 & 12.5 & 14 & 14.1 \\
\hline
\end{tabular}

\section{Bbej ta Nijj-CFU: $31.3 \%$}

Seed must be pure

The seed storage is an old practice of the Indus civilization. ${ }^{18}$ The centuries-old practice is continued. However, before the seed is stored, it is processed. The peasants, in the countryside of Sindh, mix leaves from the Neem tree (Azadirachtaindica) with seeds to keep away the mice and bugs. ${ }^{19}$ Another, old method to clean the indented sowing seed from the wild seed is to separate the wild weeds and seeds by the hand. ${ }^{20}$ The cleaned and solid seed helps the peasants, in so many ways, such as less number of weeding is grown which would otherwise hamper the growth of the crop and add on the peasant's labor. Finally, at harvesting and winnowing time, peasant tries to keep away the weed seeds from the crop seeds. Therefore, 'Bbej ta Nijj', the proverb has real meaning in the life of the peasant.

\section{JaehroBbijj, TahrroSalo- CFU: $20.2 \%$}

The seedling copies the seed

The proverb under discussion is very much relevant to the previous one. The health and solidness of the seed have a proportional relationship with the growth as well as the survival rate of the seedling. ${ }^{21}$ Thus, peasant generally cares about the seed, and it starts from harvesting, cleaning and storing. On the other hand, this proverb is also uttered on the occasion when a person's behavior is indecent. Thus, a disapproval message is passed. Its implied meaning states that a child copies the attitude of his father and mother or elders.

\section{ChhidiPokh, Dumba Sang - CFU: $17.2 \%$}

Better harvest is obtained with scattered seedlings

The aforesaid proverb is related to the peasants' practical learning. It tells that the crops give good harvest, while its seedlings are planted at the required distance. Mostly, the crops which have stems or trunk are planted at certain distances. ${ }^{22}$ 
Another step to get better harvest is to plant the seeds at the ridges by observing the principle of the required distance between the seedlings. ${ }^{23}$ However, this proverb is frequently referred to the crops like millet, sugarcane, and some vegetables which have stems. Socially, on certain occasions, this proverb is used to remind that strong friendship needs a gap in the meetings.

\section{Table 4: Theme, Proverbs' Frequency, Percentage at Villages and Cumulative Frequency \& Percentage}

\begin{tabular}{|c|c|c|c|c|c|c|c|c|c|}
\hline \multicolumn{10}{|c|}{ Theme: Tillage and Home Affairs } \\
\hline \multirow{2}{*}{ S. No } & \multirow{2}{*}{ Proverbs } & \multicolumn{2}{|c|}{$\begin{array}{c}\text { Karo Khahu } \\
\text { (35 Participants) }\end{array}$} & \multicolumn{2}{|c|}{$\begin{array}{c}\text { Boriri } \\
\text { (40 Participants) }\end{array}$} & \multicolumn{2}{|c|}{$\begin{array}{l}\text { Shah AwaisKarni } \\
\text { (24 Participants) }\end{array}$} & \multicolumn{2}{|c|}{$\begin{array}{l}\text { Cumulative } \\
\text { (99 Participants) }\end{array}$} \\
\hline & & Frequency & $\%$ & Frequency & $\%$ & Frequency & $\%$ & Frequency & $\%$ \\
\hline 1 & $\begin{array}{l}\text { GhaneZalenGhar Na Hale } \\
\text { GhaneMurrsen Har Na Hale - The } \\
\text { home becomes disarray when } \\
\text { managed by many women; no one } \\
\text { tills when too many men are } \\
\text { responsible to plough }\end{array}$ & 18 & 51.4 & 18 & 45.0 & 12 & 50.0 & 48 & 48.5 \\
\hline 2 & $\begin{array}{l}\text { Hari Har, ZalGhar-Plough suits the } \\
\text { peasant, home suits the woman }\end{array}$ & 10 & 28.6 & 9 & 22.5 & 5 & 20.8 & 24 & 24.2 \\
\hline 3 & $\begin{array}{l}\text { Har Halaenn Solo, GharHalennO'lo } \\
\text { - It is easy to till the land, rather to } \\
\text { manage the affairs of the home }\end{array}$ & 8 & 22.9 & 8 & 20.0 & 4 & 16.7 & 20 & 20.2 \\
\hline 4 & $\begin{array}{l}\text { Jethi Har, ThetheGhar-Where there } \\
\text { is the plough, there is home }\end{array}$ & 4 & 11.4 & 5 & 12.5 & 3 & 12.5 & 12 & 12.1 \\
\hline
\end{tabular}

1. GhaneZalenGhar Na Hale, GhaneMurrsen Har Na Hale-CFU: $48.5 \%$

The home becomes disarray when managed by many women; no one tills when too many men are responsible to plough

The proverb talks that cultivation is one's own responsibility and likens the situation by giving responsibility to several women to manage the household. Consequently, no woman bounds herself to the affairs of the house. Similarly, when more than one man is responsible for the land, then in such a situation, each one assumes that someone else will perform the task. ${ }^{24}$ Resultantly, no one could beheld responsible for the work not (or poorly) done.

\section{Hari Har, ZalGhar-CFU: $24.2 \%$}

Plough suits the peasant, home suits the woman

Sindhi society, like other evolving societies, took normal routes to move on the development ladder, especially in agriculture production. Therefore, it needed manpower in the form of the peasants to work in the fields, and another workforce at the home was also needed to prepare meals, manage household chores, and the most important part of the unpaid job was to prepare the labor force. ${ }^{25}$ However, women from a poor segment of the society actively participated in the field, but women who belonged to a relatively better section of the rural areas remained at home and spent their time in managing household affairs. ${ }^{26}$ 
3. Har Halaenn Solo, GharHalennO'lo - CFU $20.2 \%$

It is easy to till the land, rather manage the affairs of the home

In rural Sindh, the women's labor is neither valued nor it is recognized. However, proverbs state that management of home affairs is challenging in compare of the tillage of the land. The proverb's usage frequency at a grassroots level recognized the women's contribution, but till now it has not become the part of the states' policy framework register the women's work at home a true labor, like any paid employment.

\section{Table 5: Proverbs' Frequency, Percentage at Villages and Cumulative Frequency \& Percentage}

\begin{tabular}{|c|c|c|c|c|c|c|c|c|c|}
\hline \multicolumn{10}{|c|}{ Theme: Peasants' Indigenous Knowledge } \\
\hline \multirow{2}{*}{ S. No } & \multirow{2}{*}{ Proverbs } & \multicolumn{2}{|c|}{$\begin{array}{c}\text { Karo Khahu } \\
\text { (35 Participants) }\end{array}$} & \multicolumn{2}{|c|}{$\begin{array}{c}\text { Boriri } \\
\text { (40 Participants) }\end{array}$} & \multicolumn{2}{|c|}{$\begin{array}{l}\text { Shah AwaisKarni } \\
\text { (24 Participants) }\end{array}$} & \multicolumn{2}{|c|}{$\begin{array}{c}\text { Cumulative } \\
\text { (99 Participants) }\end{array}$} \\
\hline & & Frequency & $\%$ & Frequency & $\%$ & Frequency & $\%$ & Frequency & $\%$ \\
\hline 1 & $\begin{array}{l}\text { Khetti Sir Saiti - Agriculture is the } \\
\text { individual's responsibility }\end{array}$ & 5 & 14.3 & 6 & 15.0 & 2 & 8.3 & 13 & 13.1 \\
\hline 2 & $\begin{array}{l}\text { Har Kahend'n Ka Hajj- One } \\
\text { shouldn't shy away from the tillage }\end{array}$ & 3 & 8.6 & 2 & 5.0 & 1 & 4.2 & 6 & 6.1 \\
\hline 3 & $\begin{array}{l}\text { Motio Ute Mar, Jite Panni Huje Tar- } \\
\text { Plant Motio, where the water is } \\
\text { abundant }\end{array}$ & 2 & 5.7 & 3 & 7.5 & 1 & 4.2 & 6 & 6.1 \\
\hline 4 & $\begin{array}{l}\text { Puchrri, Buchhrri-land at the tail- } \\
\text { end is the trouble }\end{array}$ & 2 & 5.7 & 4 & 10.0 & - & 0.0 & 6 & 6.1 \\
\hline 5 & $\begin{array}{l}\text { JekoHanniKodhar, TahenKheDukar } \\
\text { Jo Kahro Dar? - Should one be } \\
\text { afraid of drought, who labors hard at } \\
\text { land? }\end{array}$ & 1 & 2.9 & 2 & 5.0 & 2 & 8.3 & 5 & 5.1 \\
\hline 6 & $\begin{array}{l}\text { Hari Jo MuhunBanieDhan - Peasant } \\
\text { heads towards land }\end{array}$ & 2 & 5.7 & 1 & 2.5 & 1 & 4.2 & 4 & 4.0 \\
\hline 7 & $\begin{array}{l}\text { Hurle Ja Hari, KhaniWo'n Zamindar } \\
\text { Kaya - Landlords sowed cotton but } \\
\text { engaged the Peasant who irrigates the } \\
\text { land through a Persian Wheel }\end{array}$ & 1 & 2.9 & 2 & 5.0 & 1 & 4.2 & 4 & 4.0 \\
\hline 8 & $\begin{array}{l}\text { SubatiPhute, PokhKhatte - Right } \\
\text { budding, winning crop }\end{array}$ & 1 & 2.9 & 1 & 2.5 & 2 & 8.3 & 4 & 4.0 \\
\hline 9 & $\begin{array}{l}\text { SuttaaFasul, KhushhalNasul- } \\
\text { bumper crops, wealthy generations }\end{array}$ & 1 & 2.9 & 1 & 2.5 & 2 & 8.3 & 4 & 4.0 \\
\hline 10 & $\begin{array}{l}\text { Pokh Sang Sa'n, Murrsu Nang Sa'n, } \\
\text { DhartiJhangSa'n - Crop looks good } \\
\text { with spikes, man with wife and the } \\
\text { land with the vegetation/forest }\end{array}$ & 2 & 5.7 & 1 & 2.5 & 1 & 4.2 & 4 & 4.0 \\
\hline 11 & $\begin{array}{l}\text { Jetro Har Otro Phar- The number of } \\
\text { tillage determines the harvest }\end{array}$ & 1 & 2.9 & 2 & 5.0 & 1 & 4.2 & 4 & 4.0 \\
\hline 12 & $\begin{array}{l}\text { Harmiae Jo Har Wari Men Be Na } \\
\text { Hale - Tricky man is not even ready } \\
\text { to plough at sandy land }\end{array}$ & 1 & 2.9 & 1 & 2.5 & 1 & 4.2 & 3 & 3.0 \\
\hline 14 & $\begin{array}{l}\text { Je HundoPait Min Danno, Ta Poe } \\
\text { ThendoRanno - A full stomach helps } \\
\text { one to become the prince }\end{array}$ & 1 & 2.9 & 1 & 2.5 & 1 & 4.2 & 3 & 3.0 \\
\hline
\end{tabular}




\begin{tabular}{|c|c|c|c|c|c|c|c|c|c|}
\hline 15 & $\begin{array}{l}\text { JahenKhanbhaniChhadi, Tahen Jo, } \\
\text { RejPanieSa'nChcha? - One who has } \\
\text { forgotten to scare the birds, what he } \\
\text { has to do about irrigating the land? }\end{array}$ & 1 & 2.9 & 1 & 2.5 & 1 & 4.2 & 3 & 3.0 \\
\hline 16 & $\begin{array}{l}\text { Pahenji Bani- Pahenjo Har-Own } \\
\text { land, own plough }\end{array}$ & 1 & 2.9 & 1 & 2.5 & 1 & 4.2 & 3 & 3.0 \\
\hline 17 & $\begin{array}{l}\text { PanjKannni Mahar Ghanni-five } \\
\text { types grains at home is a sign of the } \\
\text { fortune }\end{array}$ & 1 & 2.9 & 2 & 5.0 & - & 0.0 & 3 & 3.0 \\
\hline 18 & $\begin{array}{l}\text { Pokh Ji Hik Aa Kherri, BbeMairri- } \\
\text { Marree - Crop means, tillage and } \\
\text { collection of produce }\end{array}$ & 1 & 2.9 & 1 & 2.5 & 1 & 4.2 & 3 & 3.0 \\
\hline 19 & $\begin{array}{l}\text { PokhjiKanno, Thea Ghanno-Sow } \\
\text { grain, get plenty }\end{array}$ & 1 & 2.9 & 1 & 2.5 & 1 & 4.2 & 3 & 3.0 \\
\hline 20 & $\begin{array}{l}\text { JetriGuddOthri Add-The number of } \\
\text { inter-culturing multiples the harvest }\end{array}$ & 1 & 2.9 & 1 & 2.5 & 1 & 4.2 & 3 & 3.0 \\
\hline 21 & $\begin{array}{l}\text { KhettiAhe Har Sa'n-Agriculture is } \\
\text { plough's function }\end{array}$ & 1 & 2.9 & 1 & 2.5 & 1 & 4.2 & 3 & 3.0 \\
\hline 22 & $\begin{array}{l}\text { KuniPhuraeji, Bbani Na Phuraeji- } \\
\text { the produce ought to be robbed, but } \\
\text { the land shouldn't be }\end{array}$ & 2 & 5.7 & 1 & 2.5 & - & 0.0 & 3 & 3.0 \\
\hline 23 & $\begin{array}{l}\text { Janji Mani ThanjiKani-The offered } \\
\text { food determines the loyalty with the } \\
\text { giver }\end{array}$ & & & 1 & 2.5 & 1 & 4.2 & 2 & 2.0 \\
\hline 24 & $\begin{array}{l}\text { Lahan Khan Larro Kayo Jahn, Har, } \\
\text { Kili, Narro Tae Tanja ZianTheya- } \\
\text { The one who doesn't avoid roots } \\
\text { beneath the bushes, may break his } \\
\text { plough }\end{array}$ & 1 & 2.9 & 1 & 2.5 & - & 0.0 & 2 & 2.0 \\
\hline 25 & $\begin{array}{l}\text { Paet Na Jinin Roti, } \\
\text { TeseenGalehMirraeeKhoti - No one } \\
\text { trusts hungry man }\end{array}$ & 1 & 2.9 & 1 & 2.5 & - & 0.0 & 2 & 2.0 \\
\hline
\end{tabular}

1. Khetti Sir Saiti-CFU: $13.1 \%$

Agriculture is individuals' responsibility

Dr. Abdul Karim Sandhilo in his book "Pajakan Ji Parr" (Root of Proverbs) has narrated an interesting story about the origin of the above-mentioned proverb. He writes that one landlord found a stone slate with scribed note UtamKheti, WadhabdarrWapar, NechNokri, PenannBekar (begging is worthless, employment is lowly, business expands quickly, but agriculture has the highest value among all). He blindly followed the proverb, but never looked after the land - neither took care of the fertilizer nor irrigated the land. After sometime, he found himself in the loss, and in irritation thrown the stone at the ground, and suddenly saw another note scribed on the other side of the stone. It read: "Khetti Sir Saiti" (Agriculture is individual's responsibility). The proverb tells that agriculture is the sole responsibility of an individual. It is so because cultivation demands individual involvement throughout the year - land preparation, sowing, planting, harvesting and storing.

\section{Motio Ute Mar, Jite Panni Huje Tar-CFU: $6.1 \%$}

Plant Motio, where the water is abundant

This proverb belongs to northern Sindh where paddy crop was commonly sown. One type of the paddy crop was called Motio by locals. Its seedlings are planted where water is in plenty. This proverb tells about the agriculture method. ${ }^{27}$ It directs that Motio needs to be planted where the water is in abundance. Later, the stagnant water in large quantity, especially in rice growing areas was associated with the increasing number of Malaria cases in comparison to the wheat cultivates areas. ${ }^{28}$ The continued 
cultivation of the rice in the upper Sindh, especially in Sukkur, ${ }^{29}$ was considered that it may add the chances of more Malaria cases in the area.

\section{Puchrri, Buchhrri-CFU: $6.1 \%$}

A land at the tail is the troubled one

The land at the end of the watercourse is called the tail land. The cultivators at the tail suffer because the head and middle users allow excess water to irrigate the lands. Although, in times of rainy season the landlords at head and middle allow the water to rush at the tail land, and it floods the lands. However, at times of dry season or delayed monsoon, those at the tail never get the due quantity of water for their crop. British people practiced Warabandi (regular turn to get the water) but it never matched with the theory. ${ }^{30}$ Thus, a tail user in comparison to the head is at a loss. ${ }^{31}$

Another observation reveals that most of the proverbs fall under the theme of the peasants' indigenous knowledge. On the other hand, the village location determined the Frequency of Usage (FU) of the proverbs. For instance, the proverb Lahan KhanLarro Kayo Jahna, har, Kili, NarroTaeTanjaZianTheya (the one who didn't avoid the hidden roots of the bushes, he has to broke his plough) has 0\% of FU in village Shah AwaisKarni. However, the FU of the same proverb in village Karo Khaho and village Boriri has $2.5 \%$ and $3 \%$ respectively. The $0 \%$ FU at village Shah AwaisKarni has roots in the topography of the village because it exists near the hilly range of Khirthar Mountain, and land preparation doesn't require full scaled land preparation interventions such as ploughing and leveling. The land is seasonally cultivated in the rainy season or some pockets are cultivated through Indus flood. Therefore, the proverb's relevance is minimum. Another proverb, which has $0 \% \mathrm{FU}$ in the same village, is KuniPhuraeji, Bbani Na Phuraji (the produce ought to be robbed, but the land shouldn't be). The reasons are contextual because it is the hilly range of Khirtharthar Mountain and the land has less value due to its type and its cultivation depends upon the uncertain sources such the seasonal rain or Indus flood. Therefore, the proverb has less importance in their immediate world. Likewise, the proverb, Paet Na Jinian Roti, TeseanGalehMarreeKhoti (no one believes the talk of the hungry man) has $0 \% \mathrm{FU}$ in the same village. The reasons are sociological because the inhabitants of the village belong to the same clan and live like an extended family. ${ }^{32}$ Therefore, in their social relations, this proverb has low weight, and the same is portrayed in FGD analysis. The last proverb which has 0\% FU is PanjKannni Mahar Ghanni (five types of grains at home is a sign of the fortune). The reasons are contextual such as the location, type of land and source of irrigation. Oftentimes, lift irrigation or cannel irrigation is also used. But there is only one crop in a year. Thus, participants in the village half-heartedly attempted to grasp the essence of the proverb.

The proverb Puchrri, Buchhrri (land at the tail-end is the trouble) has highest FU at village Boriri. The ground realities have induced the participants to rank it so as the reason lies in the mode of irrigation. The village lands are irrigated through formal canal irrigation, and the peasants at the tail face the difficult situation in case of shortage or abundance of water. Due to this, at one hand loss is occurring, and on the other hand quarrel within the community also erupts. Therefore, the land at the end of the watercourse resembles trouble. Likewise, the same proverb has second last FU percentage at village Karo Khaho. 


\section{Conclusion}

The proverbs related to agriculture are also one aspect of folk wisdom. However, these proverbs enrich the conversation and play a vital role to share the worldview based on peasants' indigenous knowledge. At the cultural front, the proverbial communication sustains the indigenous knowledge. But the academia has not given adequate focus to the folk wisdom of peasants and their perspective about land and agriculture in Sindh. These proverbs provide an opportunity for the peasants to tell about their world outlook and learning. The described proverbs have space-societal relevance, and their usage is a convincing way to communicate about agriculture and share its processes and procedures. During the group discussion, it was observed that older people who were somehow associated with agriculture were well conversant to tell what type of the proverb is uttered in what situation. On the other hand, some retired primary teachers were also confident in the conversation. The proverbs are a better way to peep inside countryside social milieu to get an indication of the people and their past. Apart from the communication and cultural aspects, these proverbs, their settings in deep socio-cultural, and economic contexts appeal the historians to look at Sindhi peasants' world through the lenses of oral history. It is one of the tasks of the contemporary folklorists and oral historians to understand the process that how proverbs are generated, how they are used in specific context, what implied meaning they communicate and set the stage for the dialogue among generations. However, the oral historians face one challenge that either in indigenous knowledge or in oral history, the upholder or communicator is not the first person, he is the one who has just retained the passed on indigenous knowledge from his elders. Thus, documentation of these traditions to validate the oral history becomes a thoughtprovoking mission.

\section{Notes}

Authors' interview with Atta Muhammad Bhambhro, Sindhologist, Hyderabad, Sindh, Pakistan, dated $15^{\text {th }}$ March 2018.

Authors' interview with Taj Joyo, writer, Hyderabad, Sindh, Pakistan, dated $11^{\text {th }}$ March 2018.

R.K.Singh and A. Dorjey, Farming proverbs: analysis of their dynamics and farmers' knowledge. 2004.

C. Sumner, "The proverb and oral society", New Political Science, 21 (1), 1999, pp. 11-31.

P. Elabor-Idemudia, The retention of knowledge of folkways as a basis for resistance. Indigenous knowledges in global contexts: Multiple readings of our world, 2000, pp. 102-119. F.L. Utley, "Folk literature: An operational definition", The Journal of American Folklore, 74 (293), 1961, pp. 193-206.

J. Penfield and M. Duru, Proverbs: Metaphors that teach. Anthropological quarterly, 1988, pp. 119-128.

P. Seitel, "Proverbs: A social use of metaphor", Genre, 2 (2), 1969, pp. 143-161.

A common saying of Kohistan (arid area), Sindh, Pakistan.

D. Cheesman, "The Omnipresent Bania:'1 Rural Moneylenders in Nineteenth-Century Sind", Modern Asian Studies, 16 (3), 1982, pp. 445-462.

H. Khuhro, The Making of Modern Sindh: British policy and social change in the nineteenth century, USA: Oxford University Press, 1999.

M.H. Panhwar, Autobiography, Jag Beti, AapBeti, Hyderabad: Phoenix Books, 2010.

G. Adamson, "'The Most Horrible of Evils': Social Responses to Drought and Famine in the Bombay Presidency, 1782-1857", in Natural Hazards and Peoples in the Indian Ocean World, New York: Palgrave Macmillan, 2016, pp. 79-104. 
D. Arnold, "Cholera and colonialism in British India", Past \& Present, (113), 1986, pp. 118151.

H.M. Panhwar, Six Thousand Irrigation History of Sindh, Karachi: Department of Culture, Government of Sindh, 2011, p. 232.

S.R. Rao, "Agriculture in the Indus Civilization", in D.P. Chattopadhyaya (G. Ed.), History of Science, Philosophy and Culture in Indian Civilization, Vol. V, Part I in Gopal Lallanji and V.C. Srivastava (Eds.), History of Agriculture in India (up to c. 1200 AD), 2008, pp. 171-202. National Research Council, Neem: a tree for solving global problems, The Minerva Group, Inc. 2002.

Author's interview with Nisar Ahmed, at village Boriri, Dadu, Sindh, Pakistan, 2018.

A.T. Moles and M. Westoby, "Seedling survival and seed size: a synthesis of the literature", Journal of Ecology, 92 (3), 2004, pp. 372-383.

Y. Reckleben, "Cultivation of maize - Which sowing row distance is needed", Landtechnik, 66, 2011, pp. 370-372.

Authors' interview with farmer Nisar Ahmed Junejo, village Boriri, Sindh, Pakistan, $19^{\text {th }}$ March 2018.

R. Techandani, Sindhi Proverbs: A Linguist and Socio-cultural Study, 2010, p. 344.

M. Luxton, More Than a Labour of Love: Three Generations Of Women's Work In The Home, Vol. 2, Canadian Scholars' Press, 1980, p. 16.

A. Khan, Women and paid work in Pakistan. Pathways of Women "s Empowerment, Karachi: Collective for Social Science Research, 2007.

R. Techandani, Sindhi Proverbs: A Linguist and Socio-cultural Study, p. 339.

J.A. Sinton, "Note on the Report on" Malaria in Sind" by Lieut-Col. McCombie Young and SAS Syed Abdul Majid (1st Note.)", Records of the Malaria Survey of India, 1 (3), 1930.

G. Covell and J. Baily, "Malaria in Sind. Part IX. Malaria in Sukkur District", Records of the Malaria Survey of India, 4 (2), 1934.

D.J. Bandaragoda, Warabandi in Pakistan's canal irrigation systems: Widening gap between theory and practice (No. 7). IWMI, 1995, p. 72.

Ibid., p. XI.

Field Observation Notes, These notes were taken during the Focused Group Discussions (FGDs) at the villages, 2018. 